\title{
Chapter 6 \\ Viable Cyanobacteria and Green Algae from the Permafrost Darkness
}

\author{
Tatiana A. Vishnivetskaya
}

\subsection{Introduction}

Photosynthetic organisms, i.e., plants, algae, cyanobacteria and photosynthetic bacteria, have developed efficient systems to harvest the light of the sun and to use the light energy to drive their metabolic reactions, such as the reduction of carbon dioxide to sugar. It is through photosynthesis that Earth's biosphere derives its energy from sunlight. On the other hands, cyanobacteria are the most ancient oxygen-releasing photosynthetic organisms on the Earth. The stromatolite fossils and carbon isotope ratios confirm that autotrophs fixing carbon via the Calvin cycle must have existed for 3.5 billion years (Schopf and Packer 1987). The characteristic fossil structures formed by cyanobacteria were discovered on the Precambrian rocks and, probably, on meteorites (Zhmur et al. 1999; Boyd 2001). There is also an opinion that green algae were originated from symbiosis of cyanobacteria and a non-photosynthetic eukaryotic ancestor (Margulis 1993; Douglas 1998), the origin of photosynthetic eukaryotes that gave rise to the first alga having occurred 1.5 billion years (Yoon et al. 2004). Early algae probably gave rise to multicellular plants (Graham 1996).

Photoautotrophic microorganisms live mostly in aquatic environments, but some unicellular and filamentous algae and cyanobacteria dwell in moist soils; others join with fungi to form lichens. A number of microscopic algae and cyanobacteria inhabit different extreme environments, such as cold waters and ice, hot springs and geysers, acid ponds or salt waters, dry hot and cold deserts. A description of diverse communities of microalgae and cyanobacteria in cold habitats such as the Arctic and Antarctic lakes, rivers, seas, sea ice, glaciers, cold soils may be found elsewhere (Malone et al. 1973; Friedmann and Ocampo 1977; Sinclair and Ghiorse 1989; Getsen 1990; El-Sayed and Fryxell 1993; Nienow and Friedmann 1993; Palmisano and Garrison 1993; Vincent et al. 1993a, b; Abyzov et al. 1998; Priscu et al. 1998; Willerslev et al. 1999; Comte et al. 2007).

Tatiana A. Vishnivetskaya

Institute of Physicochemical and Biological Problems in Soil Science, Russian Academy of Sciences, 142290, Pushchino, Moscow Region, Russia; Current address: Oak Ridge National Laboratory, Biosciences Division, Oak Ridge, Tennessee 37831, USA

vishnivetsta@ornl.gov 


\subsection{Cyanobacteria and Green Algae from Permafrost Environments}

\subsubsection{Permafrost}

Permafrost is defined as a subsurface frozen layer, primarily soil or rock, which remains frozen for more than 2 years. The age of permafrost ranges from a few thousand years up to 2-3 million years and even older in Antarctica. Permafrost makes up more than $20 \%$ of the land surface of the Earth, including $82 \%$ of Alaska, $50 \%$ of Russia and Canada, 20\% of China, and most of the surface of Antarctica (Harris 1986; Williams and Smith 1989). Permafrost underlies the glaciers and soils of polar and alpine regions. Permafrost soils contain about $20-70 \%$ of ice and $1-7 \%$ of unfrozen water in the form of salt solutions with low water activity $\left(a_{\mathrm{w}}=0.85\right)$ (Gilichinsky et al. 1993). Since life depends upon liquid water, permafrost is one of the most extreme environments on the Earth. In addition, permafrost is characterised by constant negative temperature, inaccessibility of nutrient supplies, and complete darkness. It is surprising to discover photoautotrophic microorganisms which need to use light energy to drive their metabolic reactions within permafrost sediments. Because of the difficulty of studying permafrost in an undisturbed form, interactions among the organisms that live in it are not yet well understood.

\subsubsection{Arctic Permafrost}

The study sites have been located on Kolyma lowland, Northeast Russia $\left(67-70^{\circ} \mathrm{N}\right.$, $\left.152-162^{\circ} \mathrm{E}\right)$. The Arctic permafrost represents an anaerobic oligotrophic environment with a mean annual temperature of $-10^{\circ} \mathrm{C}$, redox potential $\mathrm{Eh}=+40$ to -250 ), and an organic carbon content in the range $0.05-7 \%$ (Gilichinsky 2002). Nitrogen in form of $\mathrm{NH}^{4+}, \mathrm{NO}^{2-}$, or $\mathrm{NO}^{3-}$ was determined (Janssen and Bock 1994). A total of 293 permafrost samples differentiated in lithology, genesis, and physico-chemical properties were screened for the presence of photosynthetic microorganisms. The distances between boreholes ranged from 50 to $300 \mathrm{~km}$. The deepest sample was from a depth of $61 \mathrm{~m}$, and the oldest sample was 3 million years old. The permafrost samples were hydrocarbonate-calcium fresh composition with a low salinity and neutral $\mathrm{pH}$, and of marine origin with significantly higher salinity and dominance of ions $\mathrm{Na}^{+}$and $\mathrm{Cl}^{-}$.

\subsubsection{Antarctic Permafrost}

The study areas have been located in the McMurdo Dry Valleys of Southern Victoria Land, Antarctica $\left(77-78^{\circ} \mathrm{S}, 160-163^{\circ} \mathrm{E}\right)$. The temperature of the Antarctic permafrost varies from $-18.5^{\circ} \mathrm{C}$ (Taylor Valley) through $-24^{\circ} \mathrm{C}$ (Beacon Valley) to $-27^{\circ} \mathrm{C}$ (Mt. Feather) (Gilichinsky et al. 2007b). The Antarctic permafrost is of 
fresh-water genesis, with the alkaline $\mathrm{pH}$, low clay content and organic matter often close to zero (0.05-0.25\%) (Wilson et al. 1996). Since the Antarctic permafrost has a low buffering capacity, the soil $\mathrm{pH}$ is sensitive to the total accumulation of soil salts (Campbell and Claridge 1987). A total of 56 permafrost samples were analysed for presence of cyanobacteria and green algae. The Antarctic samples were not so anaerobic (redox potential $\mathrm{Eh}=+260$ to +480 ), and the gaseous phase contained oxygen, nitrogen, methane, carbon dioxide, etc. (Rivkina and Gilichinsky 1996; Wilson et al. 1996).

\subsubsection{Permafrost Sample Collection}

The permafrost samples were obtained by slow rotary drilling without the use of any drilling solutions between 1991 and 1999. Evaluation of the aseptic sampling methods and contamination controls was done (Khlebnikova et al. 1990; Juck et al. 2005). The surface of extracted frozen core was trimmed away with a sterile knife, then immediately divided into sections of $5 \mathrm{~cm}$ long, placed in presterilized aluminum tins, sealed, and placed in frozen storage. All samples remained frozen throughout this process and during transport. In the laboratory, frozen samples were fractured in a class II positive-flow hood with a sterile knife, and only sections internal to the core were taken for microbiological analysis using sterile forceps (Shi et al. 1997; Rivkina et al. 1998).

\subsubsection{Isolation and Identification}

For isolation of photoautotrophic microorganisms, prolonged enrichments (8-18 weeks) of thawed but otherwise undisturbed permafrost samples under continuous illumination (1,000 lx) were applied. The enrichment cultures in BG11 (Rippka 1988), Bristol (Gollerbakh and Shtina 1969), BBM (Brown and Bold 1964) media were incubated at 4 and $20^{\circ} \mathrm{C}$. Enrichments were re-examined weekly to document biodiversity (Table 6.1).

Isolates were initially examined by measuring of the fluorescence excitation spectra at $686 \mathrm{~nm}$ (Vishnivetskaya et al. 2001). Identification of algae and cyanobacteria was based on morphological (Komarenko and Vasil'eva 1978; Rippka et al. 1979; Andreeva 1998) and phylogenetic (Nubel et al. 1997; Krienitz et al. 2003) criteria. DNA was extracted from cyanobacteria (Smoker and Barnum 1988) and green algae (Fawley and Fawley 2004). Bacteria-specific (8F and 1492R) (Weisburg et al. 1991) and cyanobacteria-specific (CYA106F and CYA781R) (Nubel et al. 1997) primers were used to amplify 16S rRNA gene from cyanobacteria. The 18S rRNA gene from the green algae was amplified with primers NS1 and 18L (Gilichinsky et al. 2007b). 
Table 6.1 The observation frequency of viable bacteria, cyanobacteria and green algae within Siberian permafrost

\begin{tabular}{|c|c|c|c|c|}
\hline \multirow[b]{2}{*}{ Sediment } & \multirow[b]{2}{*}{ Age (years) } & \multicolumn{3}{|c|}{ Observation frequency $^{\mathrm{a}}(\%)$} \\
\hline & & Bacteria & Cyanobacteria & Green algae \\
\hline Lake-swamp loam & Holocene $(1,000-10,000)$ & 91 & 17 & 50 \\
\hline $\begin{array}{l}\text { Alluvium sandy } \\
\text { loam }\end{array}$ & $\begin{array}{l}\text { Late Pleistocene } \\
\qquad(20,000-30,000)\end{array}$ & 80 & 9 & 18 \\
\hline Channel-fill sands & $\begin{array}{l}\text { Late Pleistocene } \\
\qquad(20,000-30,000)\end{array}$ & 40 & 0 & 0 \\
\hline $\begin{array}{l}\text { Marine (littoral) } \\
\text { sands }\end{array}$ & $\begin{array}{l}\text { Middle Pleistocene } \\
\qquad(100,000-200,000)\end{array}$ & 40 & 0 & 0 \\
\hline $\begin{array}{l}\text { Lake-alluvium } \\
\text { loam and sandy } \\
\text { loam }\end{array}$ & $\begin{array}{l}\text { Middle Pleistocene } \\
\qquad(200,000-600,000)\end{array}$ & 90 & 8 & 39 \\
\hline $\begin{array}{l}\text { Lake-alluvium } \\
\text { loam and sandy } \\
\text { loam }\end{array}$ & $\begin{array}{l}\text { Late Pliocene-early } \\
\text { Pleistocene (0.6-1.8 } \\
\text { millions) }\end{array}$ & 38 & 6 & 15 \\
\hline $\begin{array}{l}\text { Lake-alluvium } \\
\text { loam and sandy } \\
\text { loam }\end{array}$ & $\begin{array}{l}\text { Late Pliocene-early } \\
\text { Pleistocene } \\
\text { (2-3 millions) }\end{array}$ & 44 & 13 & 9 \\
\hline
\end{tabular}

${ }^{a}$ Two hundred and ninety three Siberian permafrost samples were studied; the observation frequency is expressed as a percentage of samples with viable microorganisms

\subsubsection{Cyanobacteria}

Thirty viable non-axenic cyanobacterial strains were isolated from 28 Siberian permafrost cores. Filamentous heterocystous (Nostocales) and non-heterocystous (Oscillatoriales) cyanobacteria were recovered (Vishnivetskaya et al. 2001). The $16 \mathrm{~S}$ rRNA genes from representative strains of each order were sequenced. Seven out of eight strains of the order Oscillatoriales were close to each other and to Leptolyngbya with identity $80-95.8 \%$, and one strain was closely related to Microcoleus with identity $96.8 \%$ (Fig. 6.1). The phylogenetic analyses were confirmed by studying the morphological features of the isolates. Cyanobacteria of the Oscillatoria-Leptolyngbya group, with narrow straight uniseriate trichomes, were often isolated from both young and old permafrost sediments. The Microcoleus-like strain $195 \mathrm{~A} 20$ grew at both $27^{\circ} \mathrm{C}$ and $4^{\circ} \mathrm{C}$, with a doubling time of $20 \mathrm{~h}$ at $24^{\circ} \mathrm{C}$. The strain 195A20 showed morphological plasticity with respect to growth temperature, trichomes usually being shorter and wider at $27^{\circ} \mathrm{C}$ than at low temperature (Vishnivetskaya et al. 2003). According to the 16S rRNA analysis, three cyanobacterial strains had close relatives within the order Nostocales (Fig. 6.1). Viable strains of the Nostoc and Anabaena formed heterocysts in the absence of a combined nitrogen source, and were characterized by different phycoerythrin/phycocyanin ratios depending on nitrogen source and light wavelength (Erokhina et al. 1999, 2000; Vishnivetskaya et al. 2001). Viable cyanobacteria were dominated by 

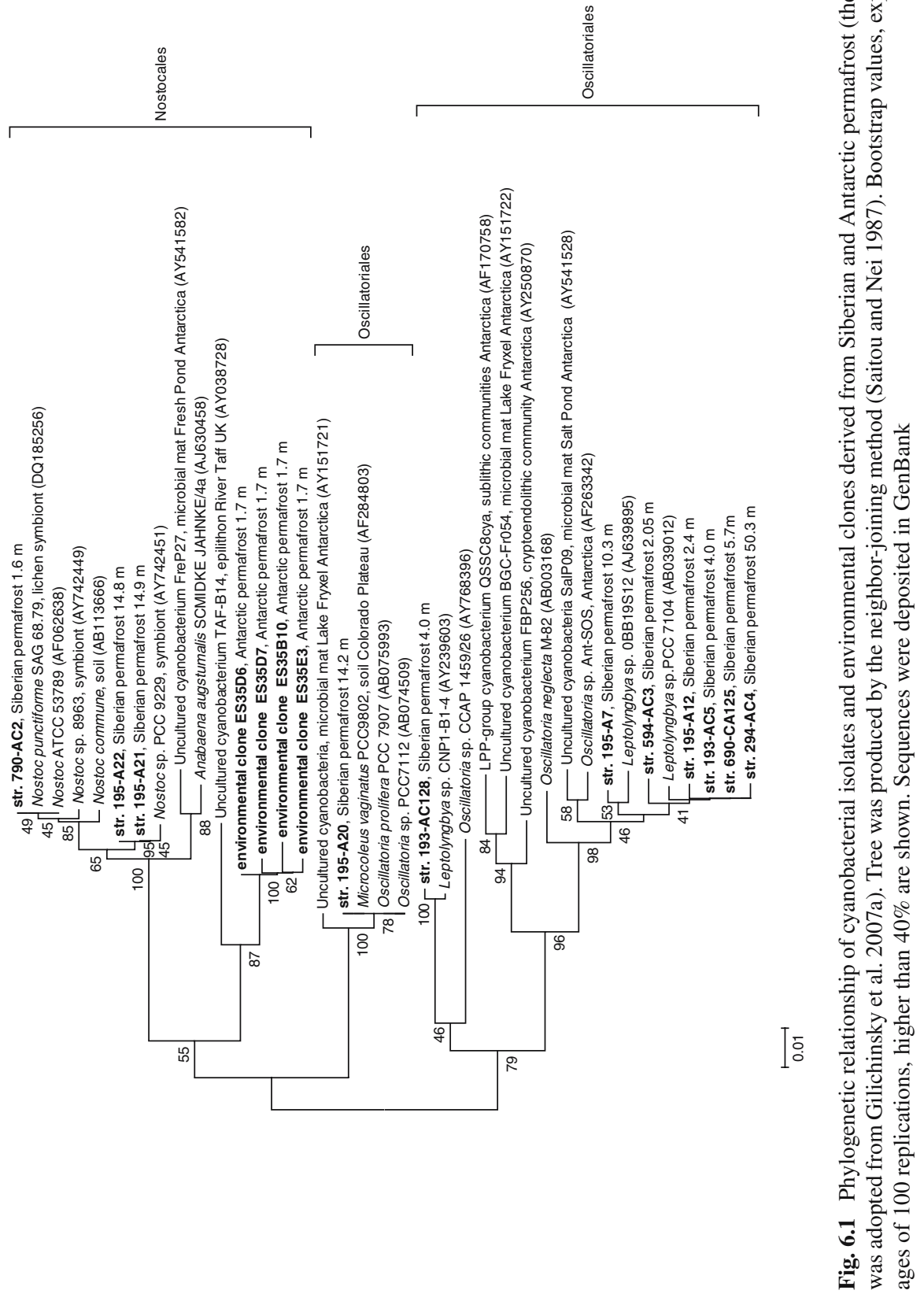
non-heterocystous filamentous cyanobacteria of the order Oscillatoriales. While no viable cyanobacteria were detected in any of 56 Antarctic permafrost samples, a few $16 \mathrm{~S}$ rRNA cyanobacterial environmental clones were obtained from the total community genomic DNA extracted from Antarctic permafrost of depth $1.7 \mathrm{~m}$ (Gilichinsky et al. 2007b). The phylogenetic analyses of the environmental clones and isolates obtained from the permafrost samples of both Polar Regions did not show any matches. Nine environmental clones were affiliated with the genus Anabaena, and they were closely related to an uncultured cyanobacterium found in river epilithon (O'Sullivan et al. 2002). We have found that viable permafrost cyanobacteria were closely related to strains and more often to uncultured cyanobacterial clones derived from a microbial mat or cryptoendolithic communities in Antarctica (Gilichinsky et al. 2007b).

\subsubsection{Green Algae}

Viable green algae were widely distributed in Siberian permafrost and were detected in 76 out of 293 permafrost cores. A total of 106 strains of green algae were isolated, and half of them, small non-motile globular cells, were identified as Chlorella spp. (Vishnivetskaya et al. 2001, 2005). Along with Chlorella spp., the species Chlorella vulgaris and Chlorella sacchorophilla and the genera Mychonastes sp., Pseudococcomyxa sp., Chodatia sp. (Chodatia tetrallontoidea), Stichococcus sp., Chlorococcum sp., Scotiellopsis sp. were identified using morphological criteria (Komarenko and Vasil'eva 1978; Andreeva 1998). Only three strains of green algae, classified as Chlorella sp., Mychonastes sp., Chlorococcum sp., were found in borehole 1/99 located in Beacon Valley, Antarctica (Gilichinsky et al. 2007b). These green algae were isolated from a permafrost layer sandwiched between buried ice horizons at depths of 14.1-14.8 $\mathrm{m}$.

The 18S rRNA gene sequences of the viable green algae from Siberian (six strains) and Antarctic (three strains) permafrost were analyzed (Fig. 6.2). Among unicellular green algae were representatives of the genera Nannochloris, Chlorella (both in the order Chlorellales), Stichococcus (order Microthamniales), and Paradoxia (uncertain position) within Trebouxiophyceae. We found that two isolates from Siberian permafrost and three isolates from Antarctic permafrost were closely related to each other and to Nannochloris sp. JL4-6 (99\%) and Chlorella protothecoides $(97.8 \%)$.

Thus, the algae isolated from subsurface permafrost sediments had previously characterized relatives from cold environments, mostly from Antarctica. Members of the Chlorellaceae family, which consists of unicellular coccoid algae with simple morphology and small size, are widespread in Antarctic cold freshwater environments and cryptoendolitic communities (Friedmann and OcampoFriedmann 1976; Friedmann 1982; Wynn-Williams 1990; Vincent et al. 1993b; Vishniac 1993). 


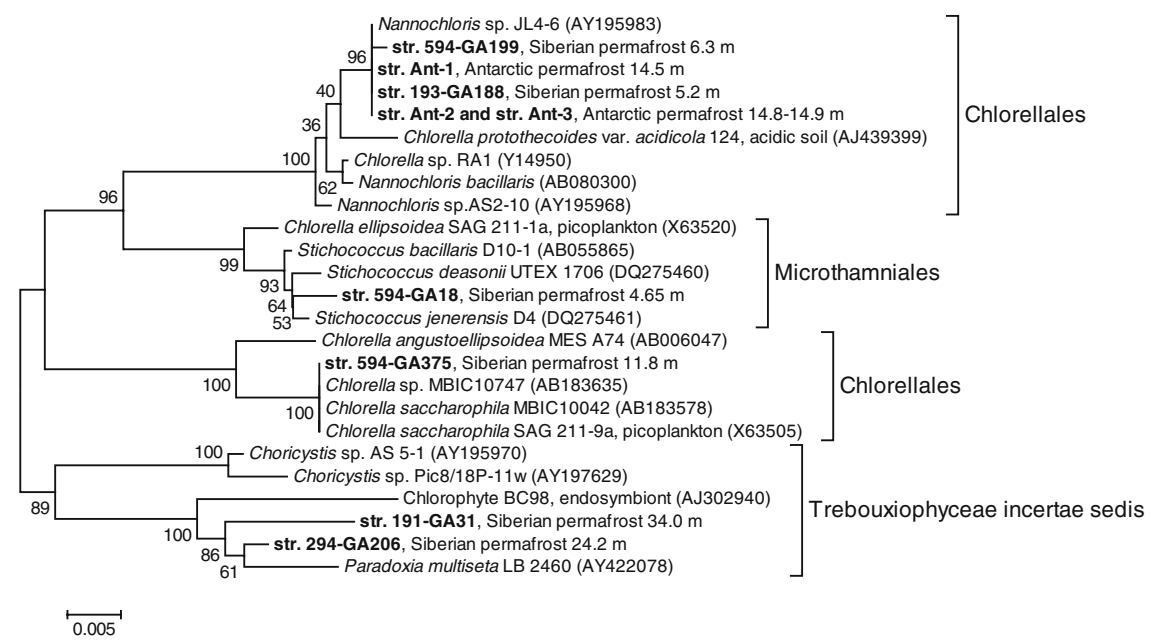

Fig. 6.2 Phylogenetic relationship of green algae isolated from Siberian and Antarctic permafrost. Tree was created as described in Fig. 6.1. Sequences were deposited in GenBank

\subsection{Life in Dark and Cold Ecosystems}

While the mechanisms which protect bacteria against the adverse conditions that include oxidation, cooling, high osmolarity/dehydration and starvation are well studied, our knowledge about adaptive and survival mechanisms of photoautotrophic microorganisms in cold and dark ecosystems such as permafrost remains limited. Obviously the upper soil and permafrost layers prevent photosynthetic activity of any chlorophyll-containing organisms. However, green algae and cyanobacteria do survive in the permafrost (Table 6.2). We have suggested that the permafrost algae survive in the deep dark permafrost sediments below freezing point for thousands and up to millions of years in the dormant or resting state (Vishnivetskaya et al. 2001). Permafrost photoautotrophic microorganisms endure the long-term impact of cold and darkness but they are readily reversible to proliferation and they do not lose the capability for photosynthesis (Vishnivetskaya et al. 2003). We have shown that isolates of the genus Chlorella grew on solid nutrient media at the dark (Vishnivetskaya et al. 2005). Recent studies have shown that contemporary unicellular algae possess the ability for heterotrophic growth as a mechanism for survival. For example, Chlamydomonas exhibited a remarkable resistance to starvation in the dark (Tittel et al. 2005); the marine dinoflagellate Fragilidium subglobosum was capable of phototrophic growth as well as of heterotrophic (phagotrophic) growth in the dark (Skovgaard 1996); unicellular green algae (Oocystis sp.) and cyanobacteria (Xenococcus sp.) were isolated from drinking water systems, and they demonstrated the ability to grow in the dark as a consequence of their heterotrophic metabolism (Codony et al. 2003). 
Table 6.2 List of the viable cyanobacteria and green algae discovered in the permafrost

\begin{tabular}{|c|c|}
\hline $\begin{array}{l}\text { Arctic } \\
\text { (Kolyma lowland, Northeast Russia) }\end{array}$ & $\begin{array}{l}\text { Antarctica } \\
\text { (Dry Valleys) }\end{array}$ \\
\hline \multicolumn{2}{|l|}{ Green algae } \\
\hline $\begin{array}{l}\text { Chlorella sp. } \\
\text { Chlore vulgaris } \\
\text { Chlorella sacchorophilla } \\
\text { Chlorococcum } \mathrm{sp} . \\
\text { Chodatia } \mathrm{sp} . \\
\text { Chodatia tetrallontoidea } \\
\text { Mychonastes sp. } \\
\text { Nannochloris } \mathrm{sp} . \\
\text { Paradoxia } \mathrm{sp} . \\
\text { Pseudococcomyxa } \mathrm{sp} . \\
\text { Scotiellopsis } \mathrm{sp} . \\
\text { Stichococcus } \mathrm{sp} .\end{array}$ & $\begin{array}{l}\text { Chlorella sp. } \\
\text { Chlorococcum sp. } \\
\text { Mychonastes sp. }\end{array}$ \\
\hline \multicolumn{2}{|l|}{ Cyanobacteria } \\
\hline $\begin{array}{l}\text { Anabaena sp. } \\
\text { Leptolyngbya sp. } \\
\text { Microcoleus sp. } \\
\text { Nostoc sp. } \\
\text { Oscillatoria } \mathrm{sp} . \\
\text { Phormidium sp. }\end{array}$ & No \\
\hline
\end{tabular}

Our observations have shown that the appearance, morphology and growth rate of ancient permafrost algae did not differ significantly from the findings on contemporary algae from cold regions. The viable permafrost green algae grew at 27,20 and $4^{\circ} \mathrm{C}$, but cyanobacteria had good growth at room temperature only (Vishnivetskaya et al. 2003). Algae had a low growth rate, with a doubling time of 10-14 days. Rise in nitrogen, phosphorus or $\mathrm{CO}_{2}$ concentrations did not affect the growth rate. On the other hand, the growth of the Nostoc sp. was completely inhibited by ammonium chloride or ferric ammonium citrate (Erokhina et al. 1999). The sources of organic ammonium such as Na-glutamine, asparagine or glycine led to the reduction of heterocysts and the development of akinetes (resistant resting cells) (Vishnivetskaya et al. 2003).

The content and composition of photosynthetic pigments in the cells of the ancient cyanobacteria and green algae based on their absorption spectra, the second-derivative absorption spectra, were studied (Erokhina et al. 1998, 2004). Comparative analysis of the absorption spectra of the Siberian permafrost cyanobacteria Oscillatoria sp., Phormidium sp., Nostoc sp., and Anabaena sp. revealed the presence of chlorophyll a, phycobiliproteins, and carotenoids in their cells (Erokhina et al. 1998). Spectral analyses of the Antarctic permafrost green algae Chlorococcum sp. and Chlorella sp. showed the presence of a low content of chlorophyll $a$, a high relative content of chlorophyll $b$, and complex composition of carotenoids (Erokhina et al. 2004; Gilichinsky et al. 2007b). The ability of Nostoc sp., and Anabaena sp. to form numerous heterocysts when grown on nitrogen-free medium, and the presence of C-phycoerythrin, 
suggested that they were capable of nitrogen fixation (Erokhina et al. 1999; Vishnivetskaya et al. 2001). The permafrost nitrogen-fixing cyanobacteria were capable of complementary chromatic adaptation, which involves the regulation of the synthesis of the photosynthetic pigments, C-phycoerythrin and phycocyanin, by red or green light (Erokhina et al. 2000; Vishnivetskaya et al. 2005).

In nature, algae inhabiting surface layers of cold regions show high resistance to the temperature fluctuations which are caused by repetitive phase transitions of water through the freezing point. Deep freezing $\left(-40^{\circ} \mathrm{C},-100^{\circ} \mathrm{C},-196^{\circ} \mathrm{C}\right)$ and desiccation, laboratory-tested on cyanobacterial and algal strains from maritime and continental Antarctica, caused little harm to cyanobacteria, but was fatal for more than $50 \%$ of the population of algae (Sabacka and Elster 2006). But how would permafrost microalgae conduct themselves in such a situation? The fact that algae have been recovered from permanently frozen sediments may suggest the resistance of algae to both primary and long-term freezing. The most critical steps where cells may receive injuries are the primary freezing and the thawing. The permafrost samples with relatively high algal biomass and numerous cultivable green algae units were exposed to repeated freeze-thaw cycles. During the experiments, it was shown that permafrost algae themselves could survive the stresses associated with transition through the freezing point. It appears that freezing induces the formation of protective envelopes and resting cells, and as a result the permafrost algae withstand dehydration and long-term inactivity (Vishnivetskaya et al. 2003).

\subsection{Conclusion}

The discovery of photoautotrophic microorganisms in permafrost is surprising, not only because of the constant subzero temperature and complete darkness of the sediments, but also because of the length of time the sediments have been frozen. These organisms may well be the only living photoautotrophs that have survived for a geologically significant period of time. These cyanobacteria and green algae inhabiting such an absolutely extreme environment exist "on the edge", near the absolute limits of their physiological potential. Therefore, permafrost cyanobacteria and green algae represent unique material for research on evolution and lowtemperature adaptation, and they defiantly possess unique mechanisms that allow them to maintain viability for very long periods of time.

Acknowledgments This research was supported by NASA Astrobiology Institute (Cooperative Agreement Number NCC-1274); and by the Russian Foundation of Basic Research (grant 01-05-05-65043).

\section{References}

Abyzov SS, Mitskevich IN, Poglazova MN (1998) Microflora of the deep glacier horizons of Central Antarctica. Microbiology 67:451-458

Andreeva B (1998) Soil aerophyl green algae (Chlorophyta: Tetrasporales, Chlorococcales, Chlorosarcinales). Nauka, Sankt-P etersburg 
Boyd SR (2001) Ammonium as a biomarker in Precambrian metasediments. Precambrian Res 108:159-173

Brown R, Bold H (1964) Comparative studies of the algal genera Tetracystis and Chlorococcum. University of Texas Publications, Dallas

Campbell IB, Claridge GGC (1987) Antarctica: Soils, weathering processes, and environment. Elsevier, Amsterdam

Codony F, Miranda AM, Mas J (2003) Persistence and proliferation of some unicellular algae in drinking water systems as result of their heterotrophic metabolism. Water SA 29:113-116

Comte K, Sabacka M, Carre-Mlouka A, Elster J, Komarek J (2007) Relationships between the Arctic and the Antarctic cyanobacteria; three Phormidium-like strains evaluated by a polyphasic approach. FEMS Microbiol Ecol 59:366-376

Douglas SE (1998) Plastid evolution: Origins, diversity, trends. Curr Opin Genet Dev 8:655-661

El-Sayed S, Fryxell G (1993) Phytoplankton. In: Friedmann EI (ed) Antarctic microbiology. Wiley-Liss, New York, pp 65-122

Erokhina LG, Vishnivetskaya TA, Gilichinskii DA (1998) The content and composition of phycobilisome pigments in cells of ancient viable cyanobacteria from Arctic permafrost. Microbiology 67:682-687

Erokhina LG, Spirina EV, Gilichinskii DA (1999) Accumulation of phycobiliproteins in cells of ancient cyanobacteria from arctic permafrost as dependent on the nitrogen source for growth. Microbiology 68:628-631

Erokhina LG, Spirina EV, Shatilovich AV, Gilichinskii DA (2000) Chromatic adaptation of viable ancient cyanobacteria from Arctic permafrost. Microbiology 69:855-856

Erokhina LG, Shatilovich AV, Kaminskaya OP, Gilichinskii DA (2004) Spectral properties of ancient green algae from Antarctic Dry Valley permafrost. Microbiology 73:485-487

Fawley MW, Fawley KP (2004) A simple and rapid technique for the isolation of DNA from microalgae. J Phycol 40:223-225

Friedmann EI (1982) Endolithic microorganisms in the Antarctic cold desert. Science 215:1045-1053

Friedmann EI, Ocampo-Friedmann R (1976) Endolitic blue-green-algae in Dry Valleys (Antarctica). J Phycol 12:20-20

Friedmann EI, Ocampo R (1977) Endolithic algae in Antarctic cold desert. J Phycol 13:22-22

Getsen M (1990) Algae as a constitution base for life of highlatitude ecosystems. Bot J 75:1641-1647

Gilichinsky D (2002) Permafrost as a microbial habitat. In: Bitton G (ed) Encyclopedia of environmental microbiology. Wiley, New York, pp 932-956

Gilichinsky DA, Soina VS, Petrova MA (1993) Cryoprotective properties of water in the Earth cryolitosphere and its role in exobiology. Orig Life Evol Biosph 23:65-75

Gilichinsky D, Vishnivetskaya T, Petrova M, Spirina E, Mamikin V, Rivkina E (2007a) Bacteria in Permafrost. In: Margesin R, Schinner F, Marx J-C, Gerday C (eds) Psychrophiles: From biodiversity to biotechnology. Springer, Berlin, pp 83-102

Gilichinsky DA, Wilson GS, Friedmann EI, McKay CP, Sletten RS, Rivkina EM, Vishnivetskaya TA, Erokhina LG, Ivanushkina NE, Kochkina GA, Shcherbakova VA, Soina VS, Spirina EV, Vorobyova EA, Fyodorov-Davydov DG, Hallet B, Ozerskaya SM, Sorokovikov VA, Laurinavichyus KS, Shatilovich A, Chanton JP, Ostroumov VE, Tiedje JM (2007b) Microbial Populations in Antarctic permafrost: Biodiversity, state, age, and implication for astrobiology. Astrobiology 7:275-311

Gollerbakh M, Shtina E (1969) Soil algae [in Russian]. Nauka, Leningrad

Graham LE (1996) Green algae to land plants: An evolutionary transition. J Plant Res 109:241-251

Harris SA (1986) The permafrost environment. Barnes \& Noble Books, Towowa New York

Janssen H, Bock E (1994) Profiles of ammonium, nitrite and nitrate in the permafrost soils. In: Gilichinsky D (ed) Viable microorganisms in permafrost. Pushchino Research Centre Russian Academy of Sciences, Pushchino, pp 27-36 
Juck DF, Whissell G, Steven B, Pollard W, McKay CP, Greer CW, Whyte LG (2005) Utilization of fluorescent microspheres and a green fluorescent protein-marked strain for assessment of microbiological contamination of permafrost and ground ice core samples from the Canadian High Arctic. Appl Environ Microbiol 71:1035-1041

Khlebnikova GM, Gilichinskii DA, Fedorov-Davydov DG, Vorob'eva EA (1990) Quantitativeevaluation of microorganisms in permafrost deposits and buried soils. Microbiology 59:106-112

Komarenko L, Vasil'eva I (1978) The fresh-water green algae from reservoirs of Yakutia. Nauka, Moscow

Krienitz L, Hegewald E, Hepperle D, Wolf M (2003) The systematics of coccoid green algae: 18S rRNA gene sequence data versus morphology. Biologia 58:437-446

Malone TC, Garside C, Anderson R, Roels OA (1973) Possible occurrence of photosynthetic microorganisms in deep-sea sediments of North-Atlantic. J Phycol 9:482-488

Margulis L (1993) Symbiosis in cell evolution: Microbial communities in the Archean and Proterozoic eons. Freeman, New York

Nienow J, Friedmann EI (1993) Terrestrial lithophytic (rock) communities. In: Friedmann EI (ed) Antarctic microbiology. Wiley-Liss, New York, pp 343-412

Nubel U, GarciaPichel F, Muyzer G (1997) PCR primers to amplify 16S rRNA genes from cyanobacteria. Appl Environ Microbiol 63:3327-3332

O'Sullivan LA, Weightman AJ, Fry JC (2002) New degenerate Cytophaga-FlexibacterBacteroides-specific $16 \mathrm{~S}$ ribosomal DNA-targeted oligonucleotide probes reveal high bacterial diversity in River Taff epilithon. Appl Environ Microbiol 68:201-210

Palmisano A, Garrison D (1993) Microorganisms in Antarctic sea ice. In: Friedmann EI (ed) Antarctic microbiology. Wiley-Liss, New York, pp 167-218

Priscu JC, Fritsen CH, Adams EE, Giovannoni SJ, Paerl HW, McKay CP, Doran PT, Gordon DA, Lanoil BD, Pinckney JL (1998) Perennial Antarctic lake ice: An oasis for life in a polar desert. Science 280:2095-2098

Rippka R (1988) Isolation and purification of cyanobacteria. Meth Enzymol 167:3-27

Rippka R, Deruelles J, Waterbury JB, Herdman M, Stanier RY (1979) Generic assignments, strain histories and properties of pure cultures of cyanobacteria. J Gen Microbiol 111:1-61

Rivkina E, Gilichinsky D (1996) Methane as paleomarker of the genesis and dynamics of the permafrost. Lithol Miner 4:183-187

Rivkina E, Gilichinsky D, Wagener S, Tiedje J, McGrath J (1998) Biogeochemical activity of anaerobic microorganisms from buried permafrost sediments. Geomicrobiol J 15:187-193

Sabacka M, Elster J (2006) Response of cyanobacteria and algae from Antarctic wetland habitats to freezing and desiccation stress. Polar Biol 30:31-37

Saitou N, Nei M (1987) The neighbor-joining method - a new method for reconstructing phylogenetic trees. Mol Biol Evol 4:406-425

Schopf JW, Packer BM (1987) Early Archean (3.3-billion to 3.5-billion-year-old) microorganisms from Warrawoona group, Australia. Science 237:70-73

Shi T, Reeves RH, Gilichinsky DA, Friedmann EI (1997) Characterization of viable bacteria from Siberian permafrost by $16 \mathrm{~S}$ rDNA sequencing. Microb Ecol 33:169-179

Sinclair JL, Ghiorse WC (1989) Distribution of aerobic-bacteria, protozoa, algae, and fungi in deep subsurface sediments. Geomicrobiol J 7:15-31

Skovgaard A (1996) Mixotrophy in Fragilidium subglobosum (Dinophyceae): Growth and grazing responses as functions of light intensity. Mar Ecol Prog Ser 143:247-253

Smoker JA, Barnum SR (1988) Rapid small-scale DNA Isolation from filamentous cyanobacteria. FEMS Microbiol Lett 56:119-122

Tittel J, Bissinger V, Gaedke U, Kamjunke N (2005) Inorganic carbon limitation and mixotrophic growth in Chlamydomonas from an acidic mining lake. Protist 156:63-75

Vincent WF, Downes MT, Castenholz RW, Howardwilliams C (1993a) Community structure and pigment organization of cyanobacteria-dominated microbial mats in Antarctica. Eur J Phycol 28:213-221 
Vincent WF, Howard-Williams C, Broady PA (1993b) Microbial communities and processes in Antarctic flowing waters. In: Friedmann EI (ed) Antarctic microbiology. Wiley-Liss, New York, pp 543-570

Vishniac H (1993) The microbiology of Antarctic soils. In: Friedmann EI (ed) Antarctic microbiology. Wiley-Liss, Inc, New York, pp 297-342

Vishnivetskaya TA, Erokhina LG, Spirina EV, Shatilovich AV, Vorobyova EA, Gilichinsky DA (2001) Ancient viable phototrophs within the permafrost. Nova Hedwigia Beiheft 123:427-442

Vishnivetskaya TA, Spirina EV, Shatilovich AV, Erokhina LG, Vorobyova EA, Gilichinsky DA (2003) The resistance of viable permafrost algae to simulated environmental stresses: Implications for astrobiology. Int J Astrobiol 2:171-177

Vishnivetskaya TA, Erokhina LG, Spirina EV, Shatilovich AV, Vorobyova EA, Tsapin AI, Gilichinsky DA (2005) Viable phototrophs: Cyanobacteria and green algae from the permafrost darkness. In: Castello JD, Rogers SO (eds) Life in ancient ice. Princeton University Press, Princeton, pp 140-158

Weisburg WG, Barns SM, Pelletier DA, Lane DJ (1991) 16S ribosomal DNA amplification for phylogenetic study. J Bacteriol 173:697-703

Willerslev E, Hansen AJ, Christensen B, Steffensen JP, Arctander P (1999) Diversity of Holocene life forms in fossil glacier ice. Proc Natl Acad Sci USA 96:8017-8021

Williams PJ, Smith MW (1989) The frozen earth. Fundamentals of geocryology (studies in polar research). Cambridge University Press, Cambridge

Wilson GS, Braddock P, Forman SL, Friedmann EI, Rivkina EM, Chanton JP, Gilichinsky DA, Fyodorov-Davidov DG, Ostroumov VE, Sorokovikov VA, Wizevich MC (1996) Coring for microbial records of Antarctic climate. Antarctic J US 31:83-86

Wynn-Williams DD (1990) Ecological aspects of Antarctic microbiology. In: Marshall KC (ed) Advances in microbial ecology, vol 11. Kluwer, Dordecht, pp 71-146

Yoon HS, Hackett JD, Ciniglia C, Pinto G, Bhattacharya D (2004) A molecular timeline for the origin of photosynthetic eukaryotes. Mol Biol Evol 21:809-818

Zhmur SI, Gorlenko VM, Gerasimenko LM (1999) Comparative morphology of modern and ancient terrestrial bacteria and microfossils from carbonaceous meteorites. Microbiology 68:739-745 